\title{
Direitos trabalhistas em construção: as lutas pela jornada de oito horas em Pernambuco, 1890-1891
}

\author{
Marcelo Mac Cord ${ }^{[1]}$
}

\begin{abstract}
Resumo
Os artífices e os operários pernambucanos não receberam o regime republicano de forma bestializada. Acreditando nas possibilidades de mudança, eles fortaleceram suas antigas lutas por direitos, que, desde o império, eram organizadas em diversas formas de associação. Atentos às demandas nacionais e internacionais dos de baixo da pirâmide social, aqueles trabalhadores criaram novas entidades que pretendiam realizar seu desejo por educação formal, melhores condições de trabalho e aprofundamento da cidadania. Novos elementos, como a comemoração do $1^{\circ}$ de Maio, do 13 de Maio e a luta pela jornada de oito horas de trabalho, somaram-se às suas tradicionais estratégias de luta. Greves, exigências por aumento de salários, anseio por participação política stricto sensu, entre outros fatores, permitiram que os operários e os artífices pernambucanos pressionassem alguns deputados estaduais. Estes últimos criaram um projeto de lei para reduzir a jornada de trabalho para oito horas, permitindo que seus beneficiários tivessem tempo para estudar. Aprovado com uma emenda, ele foi posteriormente reprovado e engavetado pelos senadores estaduais. $\mathrm{O}$ artigo analisa toda essa efervescência que mobilizou capital e trabalho em um dos principais estados brasileiros no alvorecer do regime republicano.
\end{abstract}

Palavras-chave: direitos trabalhistas; classe trabalhadora; luta de classe.

\section{Labor laws in construction: the strugle for the eight hour shift in Pernambuco, 1890-1891}

\begin{abstract}
The pernambucanos craftsmen and factory workers (from the state of Pernambuco) did not receive the republican regimen in a bestialized manner. Believing in the possibilities of change, they strengthened their old struggles for rights, which, since the empire, were organized in various forms of association. Attentive to the national and international demands of those on the bottom part of the social pyramid, those workers created new entities that intended to carry out their wish for a formal education, better working conditions and a deeper citizenship. New elements such as the celebration of May $1^{\text {st }}$, May $13^{\text {th }}$ and the struggle for the 8-hour work journey were added to their traditional struggle strategies. Strikes, demands for salary increase, craving for stricto sensu political participation, among other factors, allowed the pernambucanos factory workers and craftsmen pressed a few state representatives. The latter created a bill for reducing the work journey to eight hours, allowing their beneficiaries to have time off to study. Approved as an amendment, the same was later defeated and shelved by the state senators. The paper analyzes all this effervescence that mobilized capital and labor in one of the major states of Brazil in the dawn of the republican regimen.
\end{abstract} Keywords: labor rights; working class; class struggle.

Droits du travail dans la construction: la lutte pour la journée de huit heures à Pernambuco, 1890-1891

\section{Résumé}

Les artisans et les ouvriers de Pernambuco n'ont pas reçu le régime républicain de forme infantile. Croyant aux possibilités de changement, ils ont renforcé leurs anciennes luttes pour les droits qui, depuis lempire, étaient organisées en divers types d’association. Attentifs aux demandes nationales et internationales des personnes composant la base de la pyramide sociale, ces travailleurs ont créé de nouvelles entités qui avaient pour but de réaliser leur désir d'une éducation formelle, de conditions de travail meilleures et d’approfondissement de la citoyenneté. De nouveaux éléments, tels que la commémoration du $1^{\text {er }}$ Mai, du 13 Mai et la lutte pour la journée de travail de huit heures se sont ajoutés à leurs stratégies de lutte traditionnelles. Les grèves, les exigences d'augmentation de salaire, le désir de participation politique stricto sensu, entre autres facteurs, ont permis aux ouvriers et aux artisans de Pernambuco de faire pression sur quelques députés de l'état. Ces derniers ont créé un projet de loi en vue de réduire la journée de travail à huit heures, ce qui permettrait aux bénéficiaires d’avoir le temps d'étudier. Approuvé avec un amendement, ce projet fut rejeté ensuite et classé sans suite par les sénateurs des états. Larticle analyse toute cette effervescence qui a mobilisé capital et travail dans un des principaux états du Brésil à laube du régime républicain.

Mots-clés: droits travaillistes ; classe des travailleurs ; lutte de classe.

\section{Derechos laborales en construcción: las luchas por la jornada de ocho horas en Pernambuco, 1890-1891}

\section{Resumen}

Los artesanos y los obreros de Pernambuco no han recibido el régimen de la forma bestializada. Creyendo en las posibilidades de cambio, han fortalecido sus viejas luchas por los derechos que, desde el imperio, se organizaban en diversas formas de asociación. Atentos a las demandas nacionales e internacionales de la parte inferior de la pirámide social, esos trabajadores han creado nuevas entidades que querían hacer en realidad su deseo de educación formal, mejores condiciones de trabajo y profundización de la ciudadanía. Se han sumado nuevos elementos tales como la celebración del $1^{\text {er }}$ de mayo, 13 de mayo, en Brasil, y la lucha por la jornada de ocho horas de trabajo a sus estrategias tradicionales de lucha. Las huelgas, las demandas de aumentos salariales, el anhelo de la participación política de stricto sensu, entre otros factores, han permitido a los obreros y artesanos de Pernambuco presionar algunos diputados estatales. Estos últimos han creado un proyecto de ley para reducir la jornada laboral para ocho horas, lo que permitiera que sus beneficiarios tuvieran tiempo para estudiar. Aprobado con una enmienda, éste se ha aprobado posteriormente y dejado de lado por los senadores estatales. El artículo analiza toda esta efervescencia que ha movilizado capital y trabajo en uno de los principales estados de Brasil en los albores del régimen republicano.

Palabras clave: derechos laborales; clase obrera; lucha de clases. 

a história social do trabalho, em sua vertente marxista mais ortodoxa, os partidos comunistas e os sindicatos são os espaços por excelência da luta de classes e da plena consciência da classe operária. Segundo esse consolidado viés explicativo, tais fenômenos históricos e sociológicos somente surgiram com o desenvolvimento do capitalismo industrial, que, entre outros aspectos, permitiu a eclosão do setor secundário, o incremento da vida urbana e a oferta de substanciais reservas de mão de obra para os donos do capital. Para os marxistas mais ortodoxos da história social do trabalho, organizações tradicionais como irmandades de artífices, corporações de ofício e sociedades mutualistas, por exemplo, são compreendidas como espaços de sociabilidade "atípicos" e "incompletos". Por conseguinte, tais formas associativas aglutinariam trabalhadores com identidades sociais "atípicas" e "incompletas". Elas ainda seriam fruto de "fases anteriores" da formação histórica da classe operária e, portanto, estariam imersas em uma teleológica espécie de "pré-história". As "velhas" entidades que chegaram aos tempos hegemônicos dos partidos comunistas e dos sindicatos foram consideradas formas de "excrescência anacrônica".

Na história social do trabalho brasileira, os estudos marxistas mais ortodoxos foram hegemônicos até a década de 1980, primando por paradigmas sociologizantes em detrimento de substanciais pesquisas empíricas com fontes do passado. Engessados por modelos, os analistas dessa importante corrente intelectual afirmaram que, antes dos anos 1930, a infraestrutura brasileira não permitiu o desenvolvimento da "verdadeira" consciência de classe entre os de baixo da pirâmide social, pois eles estariam submetidos a formas "pré-capitalistas" de produção - e, consequentemente, de associação. Ainda segundo os marxistas mais ortodoxos que militaram na história social do trabalho brasileira, somente com a chamada "Era Vargas" o país teria encontrado condições para desenvolver o capitalismo, a moderna urbanização e a indústria em suas formas mais complexas. No bojo desse processo, o Partido Comunista Brasileiro (PCB) e os sindicatos teriam conquistado força como expressões superestruturais da nova base econômica, possibilitando aos operários tomarem plena ciência da exploração do homem pelo homem e de seu papel social como classe revolucionária. ${ }^{3}$

Nas últimas três décadas, novas pesquisas acadêmicas sobre a formação da classe operária brasileira relativizaram a referida rigidez teórica. Perdeu espaço o essencialismo que moldou as experiências dos sujeitos que viveram do suor do próprio rosto na fôrma explicativa dos analistas. Nesse sentido, mas

${ }^{2}$ A crítica à compreensão teleológica da formação da classe operária foi muito bem desenvolvida pelos intelectuais marxistas ingleses da New Left. Merece menção especial E. P. Thompson, que, sem abrir mão do materialismo histórico, criticou a formação da classe operária como uma espécie de necessidade histórica, fruto do devir. Para o autor, a construção da classe operária precisa dialogar com o processo histórico, que exige dos analistas especial atenção aos sujeitos, à crítica aos modelos e à empiria. Em especial, consultar Thompson (1981 e 1997).

${ }^{3}$ Para conhecer o debate, ver, entre outros, Rodrigues (1968), Pinheiro (1975, p. 120-131), Negro (1996, p. 40-61), Hall e Pinheiro (1985, p. 95-119), Gomes (2004, p. 157-186), Gomes e Ferreira (1987, p. 11-40), Fortes et al. (1999), Batalha (2003, p. 145-158, e 1991-1992, p. 111-124) e Batalha et al. (2004). 
sem abandonar o referencial marxista, houve avanços significativos nos estudos tanto do período posterior aos anos 1930 quanto da Primeira República. ${ }^{4}$ Mais recentemente, outras investigações seguiram alargando suas balizas temporais até o Império do Brasil, permitindo que conhecêssemos as demandas da até então pouco conhecida "classe artística", composta por artífices e suas associações. ${ }^{5}$ Outro panorama que se descortinou é a superação do paradigma que restringiu ao Rio de Janeiro e a São Paulo o protagonismo na formação da classe operária nacional. ${ }^{6}$ Da mesma forma, a historiografia tem problematizado o papel hegemônico que foi dado aos imigrantes europeus, trabalhadores brancos, em sua constituição. Isso tem permitido, por exemplo, demolir a pretensa "anomia" e "incapacidade" dos negros para atuarem como sujeitos históricos na sociedade pós-abolicionista e em seus mundos do trabalho. ${ }^{7}$

\section{Na história social do trabalho brasileira, os estudos marxistas mais ortodoxos foram hegemônicos até a década de 1980}

Tributário dos novos estudos, o texto que entrego ao leitor é fruto de minha atual pesquisa, que dialoga com outras que desenvolvi na última década. Há um problema central que as conduz: compreender o que motivou a organização formal de certas categorias de trabalhadores pernambucanos no transcorrer do século XIX. A problemática é extremamente instigante, pois exige que enfrentemos as mais rígidas explicações sobre a formação da classe operária nacional. Em outras pesquisas sobre o Recife oitocentista, recortadas no período em que vigia o escravismo, demonstrei como era importante para os descendentes de africanos que eram brasileiros, livres e artífices qualificados dissociarem suas imagens do estigma da escravidão e do defeito mecânico. Por meio do mutualismo, tal estratégia foi utilizada para conseguir serviços e buscar respeitabilidade pública (Mac Cord, 2012). Neste artigo, observaremos as conexões entre as "velhas" e as "novas" lutas de certas categorias de trabalhadores pernambucanos no alvorecer do regime republicano, assim como suas organizações, estratégias, práticas e relações políticas. As perspectivas thompsonianas são fundamentais nesta leitura, especialmente quando o pesquisador discute a formação da classe operária como processo histórico reconstruído por meio do trabalho empírico com as fontes (Thompson, 1981 e 1997).

As fontes da atual pesquisa invisibilizam a cor do trabalhador, mas lido com mercados de trabalho que receberam pouquíssimos imigrantes no final

${ }^{4}$ Entre outros, consultar Pinheiro e Hall (1979 e 1981), Batalha (2000), Castellucci (2008), Forte (2004) e Fontes (2007).

5 Entre outros, consultar Mac Cord (2012), Lacerda (2011) e Jesus (2006, p. 285-304).

${ }^{6}$ Entre outros, consultar Petersen (1995, p. 129-153) e Lorner (2001).

${ }^{7}$ Entre outros, consultar Cruz (2000, p. 243-290), Negro e Gomes (2006, p. 217-240), Lara (1995, p. 43-56, e 1998, p. 25-38), Chalhoub e Silva (2009, p. 11-50) e Mattos (2008). 
do século XIX e continuaram contratando descendentes de africanos. ${ }^{8} \mathrm{Em}$ meu ponto de vista, as conexões entre as "velhas" e as "novas" lutas de certas categorias de trabalhadores pernambucanos no alvorecer do regime republicano também se ancoram em uma demanda historiográfica enunciada por Ana Maria Rios e Hebe Mattos (2007, p. 55): o mundo do trabalho nas sociedades pós-emancipação exigiu a construção de pontes que o ligasse à cidadania e à conquista de direitos. Por esse motivo, parece evidente que a campanha pelas oito horas de trabalho em Pernambuco, pouquíssimos anos após a abolição, vai ao encontro do que Flávio Gomes e Maria Helena Machado (2015, p. 36-40) chamaram de ensaio de liberdade em um mundo sem escravidão. E esse ensaio, no recorte espaçotemporal proposto neste artigo, exigiu que os trabalhadores que povoam meu texto lutassem contra a precarização de sua liberdade e de sua mão de obra por meio da escolarização, da participação política stricto sensu, da conquista/manutenção de privilegiado status social e da mais expressiva aproximação com o movimento operário nacional e internacional.

\section{O alvorecer da república e as organizações de trabalhadores especializados em Pernambuco}

No Diário de Pernambuco, logo após a proclamação da república, observamos que setores mais conservadores do estado temiam possíveis perdas políticas, econômicas e sociais com a mudança de regime. Apesar de a folha afirmar que a população mais pobre assistiu embasbacada à chegada da novidade política, havia o temor de que, logo após o evento, apoiassem golpes e revoluções. A liderança de José Mariano, político exaltado atento às demandas das camadas médias urbanas, por exemplo, alimentava essas inseguranças nas velhas aristocracias pernambucanas (Zacarias, 2009, p. 39, 41 e 46). Na mesma semana, Aristide Lobo, em carta publicada no Diário Popular, folha paulista, registrou impressões semelhantes quanto aos acontecimentos de 15 de novembro de 1889, dizendo que a maior parte do povo assistiu bestializada à proclamação da república. Em um ou outro caso, como podemos deduzir, a pretensa passividade dos de baixo teria sido a primeira reação às novas conjunturas. $\mathrm{Na}$ historiografia política brasileira mais tradicional, relatos desse tipo acabaram por induzir as explicações dos analistas. Existiu certo consenso de que os brasileiros com vida política, econômica e social precarizada estiveram alheios à proclamação da república e a seus desdobramentos. ${ }^{9}$ É preciso relativizar leituras desse tipo, contudo. ${ }^{10}$

Ao folhearmos os principais jornais pernambucanos, de maior ou de menor circulação, observamos organizações de trabalhadores muito ativas e que

\footnotetext{
${ }^{8}$ Antes da abolição, o silêncio sobre a cor era uma estratégia dos negros livres e libertos para desfrutarem de uma liberdade mais plena. Após o dia 13 de maio, uma forma de não precarizar a liberdade em tempos de racismo e restrição da cidadania (Mattos, 1998; Rios e 2005).

${ }^{9} \mathrm{O}$ trabalho mais representativo dessa corrente analítica foi o de Carvalho (2013).

10 Novos estudos seguem relativizando a noção de que as camadas populares tenham recebido a república de forma bestializada. Um exemplo basilar é Mello (2007).
} 
certamente depositaram esperanças nos novos tempos republicanos. Entre os anos 1890 e 1891, por exemplo, registramos a instalação do Club Artista Nacional, a reforma dos estatutos da Liga Operária de Pernambuco, os encontros da União Artística Republicana, a aprovação dos estatutos e os encontros da Sociedade União Progressiva Central das Artes, a escolha da nova diretoria da Sociedade União Beneficente dos Maquinistas, os socorros prestados pela Associação dos Práticos, as atividades da Sociedade Regeneradora dos Artistas, os encontros do Partido Operário, as reuniões do Congresso Artístico Operário de Pernambuco, os trabalhos da Sociedade União Artístico-operária Olindense, a formação do Núcleo dos Operários, as reuniões da Sociedade dos Artistas Mecânicos e Liberais, os serviços oferecidos pela Sociedade Auxiliadora das Artes Férreas, a posse da diretoria do Congresso Artístico Beneficente, as atividades da Associação Beneficente dos Empregados da Ferrocarril Pernambucana, a abertura da Associação Beneficente dos Cigarreiros, a posse da diretoria do Núcleo Artístico Instrutivo e o surgimento da Sociedade União Tipográfica Pernambucana. ${ }^{11}$

Apesar dessa ebulição após o dia 15 de novembro de 1889, seria muito ingênuo acreditar que os trabalhadores pernambucanos se organizassem da noite para o dia. No transcorrer do século retrasado, houve uma forte cultura associativa entre certos grupos de pernambucanos que dependiam de sua força de trabalho - especialmente após 1860, com a aprovação da Lei dos Entraves. ${ }^{12}$ Em outros textos, demonstrei que as sociedades mutualistas foram muito importantes para o fortalecimento de identidades sociais e de lutas por melhores condições de vida entre aqueles que circulavam no mundo do trabalho, eram livres e tinham pele escura. Entre elas, por exemplo, pedreiros e carpinas procuravam proteção na Imperial Sociedade dos Artistas Mecânicos e Liberais. No Montepio Popular Pernambucano, de forma geral, encontravam meios de auxílio mútuo os trabalhadores nacionais. Ainda no período imperial, encontramos também a Associação Tipográfica Pernambucana, a Sociedade União Beneficente dos Artistas Seleiros, a Sociedade Arte e Amizade dos Marceneiros, a Associação dos Artistas Alfaiates e a Sociedade União Beneficente dos Cocheiros (Mac Cord, 2012). Nos anos 1870, projetos vindos de baixo da pirâmide social procuraram reunir todos esses grupos em uma só associação. A União Artística, por exemplo, pretendia fortalecer a luta dos artesãos por direitos políticos (Mac Cord, 2009, p. 41-63).

A intensa mobilização de certas categorias de trabalhadores pernambucanos, após o dia 15 de novembro de 1889, encontra justificativa em nossa historiografia social do trabalho. Logo nos primeiros anos do regime republicano,

\footnotetext{
" Na ordem: Diário de Pernambuco, 10 e 18 jan., 6 fev., 13 e 29 mar., 9 e 29 jul. 1890. Livro de officios e documentos recebidos de 2 jan. 1888 a 8 out. 1890, s.n., LI 091 Oj32, Sociedade dos Artistas Mecânicos e Liberais, Coleção Liceu de Artes e Ofícios. Recife: Universidade Católica de Pernambuco (Unicap); Diário de Pernambuco, 7 ago., 23 set., 18 e 29 out. 1890; Diário de Pernambuco, 14 jan. 1891; O Artista, 3 fev. 1891; Diário de Pernambuco, 20 mar. 1891; Gazeta da Tarde, 25 abr. 1891; Jornal do Recife, 19 e 24 maio 1891; Diário de Pernambuco, 7 jul. 1891.

12 Para saber mais sobre a Lei dos Entraves, que também procurou regular as sociedades mutualistas, consultar Lacerda (2011).
} 
segundo alguns intérpretes, a classe trabalhadora nacional ficou extremamente motivada para lutar por mais autonomia política, econômica, cultural e social. Isso porque os de baixo acreditaram na possibilidade de mudança com o novo regime. ${ }^{13}$ Obviamente, nos primeiros anos do período em quadro, cada setor da classe trabalhadora construiu uma maneira peculiar de atuar. Ela era heterogênea em seus interesses, composição, cultura associativa e demandas sociais. $\mathrm{O}$ leitor atento percebeu que a maior parte dos grupos que elenquei era formada por trabalhadores especializados. Segundo Claudio Batalha, eles encontraram melhores condições para se organizarem em ligas e partidos, assim como para lutar por direitos políticos e sociais stricto sensu. Para o autor, entre eles havia uma experiência organizativa que alicerçou a construção de entidades mais orgânicas. Do transcorrer do século XIX até a década de 1910, os sindicatos por ramo de indústria, por exemplo, com artesãos e operários especializados, tiveram mais visibilidade do que os sindicatos fabris (Batalha, 2010, p. 170-171).

No alvorecer da república, em Pernambuco, os trabalhadores especializados com mais experiência organizativa ainda ambicionavam construir uma entidade que representasse toda a classe ou atrair para alguma existente essa missão. Assim como na década de 1870, esses projetos estiveram marcados por tensões políticas. No mês de julho de 1890, encontramos alguns casos que confirmam minha afirmação. A Sociedade Centro Artístico marcou uma reunião com todas as sociedades artísticas estabelecidas no estado, que seria realizada no Liceu de Artes e Ofícios de Recife. ${ }^{14}$ As fontes não indicam a ocorrência do evento. Podemos sugerir que a proponente não tinha representatividade para atrair e aglutinar suas congêneres. A Liga Operária de Pernambuco, por meio de seu jornal, Gazeta dos Operários, afirmou representar a classe operária pernambucana. ${ }^{15}$ A Sociedade dos Artistas Mecânicos e Liberais, existente desde a década de 1840, não participou de um encontro promovido pela Liga Operária de Pernambuco, por se sentir desprestigiada na organização do Partido Operário de Pernambuco. ${ }^{16}$ Por fim, a Sociedade Progressista Central das Artes conseguiu que várias associações comparecessem ao encontro que promoveu. $\mathrm{O}$ objetivo da assembleia era criar um corpo consultivo que representasse toda a classe. A Liga Operária de Pernambuco não apareceu. ${ }^{17}$

Na busca de legitimidade e reconhecimento, a intensa atividade política e organizacional dos trabalhadores especializados pernambucanos extrapolou os limites estaduais. Eles estavam atentos ao que acontecia no cenário nacional e internacional. Em maio de 1890, observamos que a Liga Operária de Pernambuco tinha uma bandeira inspirada na dos Estados Unidos da América e mantinha

\footnotetext{
13 Jofilly (2012, p. 148), Gomes (2005, p. 36-39 e 47), Batalha (2006, p. 107) e Mattos (2008, p. 118-120).

14 Atas da Imperial Sociedade dos Artistas Mecânicos e Liberais de Pernambuco, 1886-1895, p. 192, LI 091 Aj188, Sociedade dos Artistas Mecânicos e Liberais, Coleção Liceu de Artes e Ofícios. Recife: Unicap. No Rio de Janeiro, em 1890, o Liceu de Artes e Ofícios do Rio de Janeiro também foi um espaço utilizado para as reuniões de trabalhadores que queriam se organizar. Do movimento, surgiu o Centro Partido Operário (Castellucci, 2008, p. 45-46).

15 Gazeta dos Operários, 15 jul. 1890.

${ }^{16}$ Atas da Imperial Sociedade dos Artistas Mecânicos e Liberais de Pernambuco, 1886-1895, p. 193, LI O91

Aj188, Sociedade dos Artistas Mecânicos e Liberais, Coleção Liceu de Artes e Ofícios. Recife: Unicap.

17 Diário de Pernambuco, 29 jul. 1890.
} 
contato com entidades tanto de Nova York quanto de cidades europeias. Em mesmo mês e ano, a entidade afirmou que seus estatutos foram baseados nos de congêneres belgas, portuguesas e norte-americanas - especialmente da Filadélfia. Reformado em janeiro de 1890, como vimos, o regulamento da Liga Operária de Pernambuco perseguia as seguintes metas: instrução de seus membros e familiares, jornada de trabalho de oito horas diárias, combate aos acidentes de trabalho, direitos trabalhistas para mulheres e crianças, aumento salarial da classe trabalhadora e arbitragem governamental nos conflitos entre patrões e empregados. ${ }^{18}$ Esses objetivos, associados àquelas relações internacionais, evidenciam o diálogo da Liga Operária de Pernambuco com as demandas da Segunda Internacional Socialista, representadas pelo "possibilismo" da social-democracia alemã e da Federação Americana do Trabalho. ${ }^{19}$

Nacionalmente, as conexões dos grupos de trabalhadores especializados pernambucanos também foram muito expressivas. Tomemos como exemplo o mês de junho de 1890. A Sociedade dos Artistas Mecânicos e Liberais comunicou a seus sócios que havia recebido um telegrama do Partido Operário do Ceará. Assinado por Anderson Ferro, o documento afirmava que a entidade era filiada ao Partido Operário, localizado no Rio de Janeiro. Ferro conclamava a criação de uma congênere pernambucana. ${ }^{20}$ A Liga Operária de Pernambuco também discutiu a montagem da mesma entidade política local, mas havia sido acionada pelos próprios dirigentes do Partido Operário da capital federal. ${ }^{21}$ Em meio a essa movimentação, Roberto Kinsman, diretor provisório do Partido Operário, partiu do Rio de Janeiro em direção à Europa. ${ }^{22}$ No trajeto, desembarcou em Salvador e foi recepcionado por comissários do Partido Operário Baiano (Castellucci, 2008, p. 75). Em seguida, chegou a Recife com

\footnotetext{
${ }^{18}$ Até aqui, tudo em Diário de Pernambuco, 15 e 25 maio 1890; Gazeta dos Operários, 15 jul. 1890.

19 O "possibilismo" da social-democracia alemã, hegemônico na Segunda Internacional Socialista, pretendia que os operários conquistassem direitos sociais por meio da participação político-eleitoral e de possíveis diálogos com a classe patronal. Apesar de a Segunda Internacional Socialista apresentar um perfil mais conciliatório, sabemos que, internamente, existiram conflitos e complexidades ideológicas que dividiram o campo das esquerdas no final do século retrasado. Em meio a toda aquela ebulição vinda de baixo da pirâmide social, os contentores encontravam certo consenso quando exigiram a criação de leis internacionais que protegessem os trabalhadores e a feitura de regulamentos que disciplinassem a jornada de trabalho em oito horas diárias. Isso sem esquecer a importância do acesso à educação para os operários e as lutas pela universalização do 10 de Maio, a grande festa do trabalhador. Até aqui, tudo em Waldenberg (1989, p. 223255), Haupt (1983, p. 356), Hobsbawm (1989, p. 79), Jofilly (2012, p. 39-40, 116-117 e 148), Fetscher (1989, p. 260) e Perrot (2010, p. 127, 130 e 134). Por sua vez, em 1890, a Federação Americana do Trabalho lutava pela jornada de oito horas de trabalho diário e pela festa do 10 de Maio como a festa do trabalho (Jofilly, 2012, p. 40). ${ }^{20}$ Atas da Imperial Sociedade dos Artistas Mecânicos e Liberais de Pernambuco, 1886-1895, p. 189, LI 091 Aj188, Sociedade dos Artistas Mecânicos e Liberais, Coleção Liceu de Artes e Ofícios. Recife: Unicap; Livro de officios e documentos recebidos de 2 jan. 1888 a 8 out. 1890, s.n., LI 091 Oj32, Sociedade dos Artistas Mecânicos e Liberais, Coleção Liceu de Artes e Ofícios. Recife: Unicap. No início do ano 1890, os trabalhadores mais qualificados da capital federal criaram o Partido Operário, inspirado nos programas da social-democracia alemã. Existiram rachas na entidade, o que se viabilizou na organização de outros grupos, como o Centro Partido Operário. Para saber mais, entre outros, consultar Pansardi (1993), Mattos (2008, p. 89-91 e 118122), Gomes (2005, p. 46-48) e Castellucci (2008, p. 45-47). Claudio Batalha afirma que esses grupos ora pleiteavam direitos sociais sem questionar os políticos, ora lutavam por direitos sociais casados com direitos políticos-eleitorais (Batalha, 2010, p. 173-175).

${ }^{21}$ Diário de Pernambuco, 18 jun. 1890.

${ }^{22}$ Roberto Kinsman Benjamim nasceu no Rio de Janeiro em 1853. Seguiu para a Europa com 3 anos de idade, onde estudou música. Retornou à cidade natal em 1876, onde atuou em entidades musicais e trabalhou em bancos. Em 1890, assumiu provisoriamente a direção do Partido Operário (Batalha, 2009, p. 33-34).
} 
festa, quando foi recebido por indivíduos que pretendiam organizar o Partido Operário de Pernambuco. ${ }^{23}$ Com essas articulações regionais, vamos ao encontro de algumas questões propostas por Silvia Petersen (1995, p. 135), no sentido de buscar a circulação de ideias comuns e a mobilidade espacial de lideranças na formação do operariado brasileiro.

\section{As organizações de trabalhadores especializados em Pernambuco e suas lutas por direitos}

As articulações nacionais e internacionais dos grupos de trabalhadores especializados pernambucanos fortaleceram suas mais diferentes lutas. Combater o emprego da mão de obra estrangeira foi uma delas. No dia 4 de setembro de 1890, a Liga Operária de Pernambuco pediu ao governador do estado que fizesse algo contra a demissão de 40 brasileiros que trabalhavam na Colônia Suassuna e na Hospedaria da Jaqueira. Para a organização, eles teriam sido substituídos por "estrangeiros inábeis e incapazes de ocuparem um lugar com dignidade". Além disso, segundo a fonte, os dispensados ainda foram "prejudicados em seus salários da quinzena vencidos". ${ }^{24}$ A briga contra o europeu que abocanhava empregos surgiu também no jornal $O$ Artista, do Congresso Artístico Operário de Pernambuco. Na "seção particular" de 3 de fevereiro de 1891, foi publicada uma matéria contra os estrangeiros que foram contratados pela Companhia Draynage, em detrimento de bons artífices recifenses. ${ }^{25}$ Em Pernambuco, a luta pelo emprego do trabalhador nacional era antiga e ganhou primeiro destaque na Insurreição Praieira, em 1848, quando artífices e caixeiros locais pegaram em armas para combater o imigrante português que ocupava funções no comércio a retalho e nas mais diversas oficinas mecânicas (Câmara, 2005; Carvalho, 2003; Mac Cord, 2012).

Nos primeiros anos do regime republicano, os trabalhadores especializados pernambucanos também tentaram garantir emprego por meio da construção de oficinas coletivas, que seriam administradas por suas associações. A Sociedade União Progressista Central das Artes foi uma delas. Fundada em 9 de fevereiro de 1890, reunia quase 400 artistas nacionais. O grupo recifense ainda tinha uma pequena tipografia e era filiado ao Congresso Artístico Operário de Pernambuco. Em fevereiro de 1891, seus diretores objetivavam montar algumas oficinas coletivas para que seus membros labutassem sem atravessadores, ou seja, sem patrões ou vendedores indiretos de seus produtos/serviços. Do lucro total auferido com as operações produtivas e comerciais, $30 \%$ seriam reservados para a formação de um montepio que beneficiasse os próprios artesãos consorciados e suas famílias. É bastante interessante observar que a Sociedade União Progressista Central das Artes pretendia atuar, simultaneamente, como

${ }_{23}$ Gazeta dos Operários, 15 jul. 1890; Diário de Pernambuco, 19 jul. 1890.

${ }^{24}$ Até aqui, tudo em Arquivo Público Estadual Jordão Emerenciano (Apeje). Diversos II, DII 45, fl. 376-377. Seção de Manuscritos, Recife.

${ }^{25}$ O Artista, 3 fev. 1891. 
entidade cooperativista e mutualista, o que garantiria ainda mais proteção a seus membros. Ainda em fevereiro de 1891, a Sociedade Auxiliadora das Artes Férreas comunicava aos interessados que tinha oficinas próprias para consertar e armar os mais diversos tipos de máquinas. ${ }^{26}$

\section{Na busca de legitimidade e reconhecimento, a intensa atividade politica e organizacional dos trabalhadores especializados pernambucanos extrapolou os limites estaduais}

No momento em que acordavam uma relação de trabalho junto ao mercado, setores da classe trabalhadora pernambucana buscavam apoio estatal quando seus interesses eram feridos. Assim como nos casos da Colônia Suassuna e da Hospedaria da Jaqueira, a Liga Operária de Pernambuco solicitou intervenção governamental em outros dois casos de demissão. Em setembro de 1891, os empregados da Estrada de Ferro Sul de Pernambuco pressionaram o engenheiro responsável pela ferrovia no sentido de demitir o chefe das oficinas. Isso porque esse encarregado havia despedido alguns oficiais que estavam sob sua supervisão. No mesmo período, o mestre daquela empresa também demitiu mais oito trabalhadores e, para piorar a situação, ainda deu um calote nos pagamentos devidos. ${ }^{27}$ Por outro lado, nas oportunidades em que o Estado era o próprio patrão, a Liga Operária de Pernambuco tentava negociar suas demandas diretamente com as autoridades públicas. Ainda em setembro de 1891, a entidade escreveu para o Congresso Nacional solicitando a manutenção do Arsenal de Marinha de Pernambuco para que seus mestres, oficiais e aprendizes continuassem empregados. Os documentos disponíveis indicam que deputados e senadores foram simpáticos ao pedido vindo de Recife. ${ }^{28}$

Entre os casos descritos, dois demonstraram a insatisfação da Liga Operária de Pernambuco com os patrões que atrasavam pagamentos. Nos primeiros meses de 1891, a própria falta de pontualidade do governo também incomodava outras categorias profissionais, como os professores primários do estado. ${ }^{29}$ Junto da luta pelo pronto pagamento dos salários da classe trabalhadora, a Liga Operária de Pernambuco também pediu ao governo que não privasse os funcionários das repartições estatais (os artífices dos arsenais, por exemplo) de seus vencimentos nos feriados, ou seja, que encarasse essas folgas como dia trabalhado. ${ }^{30}$ Contudo, as vozes dos trabalhadores especializados, estivessem eles mais ou menos organizados, ressoaram com mais intensidade quando exigiram

${ }^{26}$ Até aqui, tudo em O Artista, 3 fev. 1891

27 Apeje. Miscelânea 1891-1892, fl. 186 e 190, Seção de Manuscritos, Recife.

${ }^{28}$ Diário de Pernambuco, 8 set. 1891; A Província, 8 set. 1891.

${ }^{29}$ Diário de Pernambuco, 5 mar. 1890.

30 Diário de Pernambuco, 2 jul. 1890 
aumentos salariais. No transcorrer dos anos 1890 e 1891, encontramos várias categorias cobrando melhores proventos. Entre elas, tipógrafos, maquinistas, alfaiates, barbeiros e sapateiros. Estes últimos, apoiados por outras categorias, acabaram se organizando na Sociedade União Progressista Central das Artes. Nas diversas manufaturas recifenses, certos operários com funções menos qualificadas também aproveitaram o embalo e marcaram posição quanto a seus vencimentos. Entre eles, cigarreiros, foguistas e carvoeiros. ${ }^{31}$

Curioso notar que boa parte dos trabalhadores que reivindicavam melhores salários atingiu seu intento. Contudo, advirto que não foi mera coincidência a vitória de diversas categorias em sua luta por direitos, como se tudo tivesse ocorrido por mero encanto ou boa vontade patronal. Grande parcela das reivindicações por mim apresentadas esteve absolutamente vinculada às lutas do $1^{\circ}$ de Maio, que foram oficializadas nos hemisfério norte em $1890 .{ }^{32}$ No Jornal do Recife de 3 de maio de 1891, observamos que várias categorias fizeram greve no dia do trabalhador e andavam pelas ruas em grande número. Ao comentar o rebuliço nos espaços públicos recifenses, o redator da nota afirmou que "não há dúvida, as greves estão na moda" - parece evidente que fez uma relação entre o que acontecia na cidade e nos países industrializados. ${ }^{33}$ No dia 2, o Diário de Pernambuco estava muito preocupado com as greves estaduais que foram deflagradas na véspera. Pedia a todos os envolvidos que agissem com prudência e calma para que fossem conciliados os interesses de patrões e empregados. ${ }^{34}$ Ambos os jornais não exageraram sobre a importância dos eventos, pois entidades como a Liga Operária de Pernambuco e o Congresso Artístico Operário de Pernambuco organizaram festas de $1^{\circ}$ de Maio, que reivindicavam, inclusive, a jornada de trabalho de oito horas. ${ }^{35}$

As elites letradas e proprietárias pernambucanas, por meio dos jornais, alardeavam os inconvenientes do socialismo e do anarquismo para alimentar o temor de seus leitores pela influência dessas ideologias nas ações dos trabalhadores estaduais. No dia 28 de janeiro de 1891, a Gazeta da Tarde anunciava que, na França, anarquistas europeus estavam reunidos em um comitê central com "sociedades niilistas e terroristas". ${ }^{6}$ Em 21 de março, ao comentar sobre política externa, centrando suas análises na França e na Espanha, A Província temia o potencial grevista e revolucionário da Festa do Trabalhador. ${ }^{37}$ No dia 3 de maio, o Diário de Pernambuco relacionava desordem e socialismo com o $1^{\mathrm{o}}$ de Maio europeu. ${ }^{38}$ Dias depois, o mesmo periódico discutiu a situação do

\footnotetext{
${ }^{31}$ Até aqui, tudo em Diário de Pernambuco, 23 ago. e 25 dez. 1890, 4 abr. 1891; Gazeta da Tarde, 6, 7, 9 e 14 abr. 1891; Jornal do Recife, 13, 25 e 26 abr. e 2, 5 e 9 maio 1891.

32 Desde 1888, existiu uma movimentação pelo 10 de Maio e pela jornada de oito horas, mas somente em 1890 tivemos a primeira festa organizada por guedistas (Perrot, 2010, p. 127 e 130). A Federação Americana do Trabalho também fez campanha pelas oito horas de trabalho no dia 10 de maio de 1890 (Jofilly, 2012, p. 40).

33 Jornal do Recife, 3 maio 1891.

${ }^{34}$ Diário de Pernambuco, 2 maio 1891.

${ }^{35}$ Diário de Pernambuco, 2 e 5 maio 1891

${ }^{36}$ Gazeta da Tarde, 28 jan. 1891.

${ }^{37}$ A Província, 21 mar. 1891.

${ }^{38}$ Diário de Pernambuco, 3 maio 1891.
} 
Velho Mundo, que temia o socialismo e o proletariado. ${ }^{39}$ Em 9 de junho, o Jornal do Recife informava que, na Europa, os "niilistas russos" mandavam mensagens secretas em latas de sardinha. ${ }^{40}$ Em 17 de julho, o Diário de Pernambuco comentava os estudos de Lombroso, que decifravam a pérfida fisionomia dos anarquistas. ${ }^{41} \mathrm{O}$ remédio para todos esses inconvenientes surgiu na Gazeta da Tarde de 18 de junho: obediência à encíclica Rerum novarum, lançada em 15 maio, na qual patrões e operários eram lembrados de seus deveres e direitos, de forma conciliatória. ${ }^{42}$

Existiu profunda relação dialética entre essas matérias publicadas nos jornais e as expectativas de setores da classe patronal. Em princípios de março de 1891, um comerciante recifense pedia a união de todos os seus pares contra os caixeiros "que não conhecem a distância que nos separa". Mais do que isso, era absolutamente contrário às associações de empregados. O inconformado patrão chegou a dizer que um sujeito chamado Fernandes Almeida era o "patrão-mor de todos os caixeiros vendilhões". ${ }^{43}$ Nos primeiros dias de maio, logo depois da greve de forneiros, mestres de masseira, cervejeiros e amassadores, os donos de padarias ficaram absolutamente revoltados com as demandas de seus funcionários, o que viabilizou um encontro da classe patronal para que discutissem assuntos de seu interesse. ${ }^{44} \mathrm{O}$ acirramento do conflito de classe no alvorecer do regime republicano também poder ser observado, por exemplo, na greve dos sapateiros. Os cigarreiros da fábrica Cybelle conclamaram o apoio de todos os trabalhadores de seu setor produtivo àquela categoria, pois era "um dever auxiliarem-se mutuamente todas as classes obreiras para o completo triunfo da integridade operária [sob o símbolo da] bandeira vermelha de sua regeneração"45 Sabemos dos significados radicais desse ícone das lutas da classe operária.

Ao mesmo tempo, se tivemos o acirramento da luta de classes, vários acordos entre patrões e empregados foram bem-sucedidos e terminaram em festa entre os antigos contentores. Os cigarreiros da fábrica Caxias não levaram muito em conta a proposta mais radical de seus colegas da fábrica Cybelle, pois, logo no dia 2 de maio de 1891, homenagearam o dono do estabelecimento por aumentar seu salário. ${ }^{46}$ Poucos dias depois, a Comissão Central dos Alfaiates agradeceu aos mestres que repactuaram os jornais de seus subordinados. ${ }^{47}$ Esse caso é modelar para discutirmos o afrouxamento das antigas relações corporativas, em que as hierarquias das oficinas eram mais respeitadas. Em Pernambuco de finais do século retrasado, rompendo com seus tradicionais costumes, os oficiais daquela arte mecânica se reuniram como empregados

39 Diário de Pernambuco, 10 maio 1891.

40 Jornal do Recife, 9 jun. 1891.

${ }^{41}$ Diário de Pernambuco, 17 jul. 1891.

${ }^{42}$ Gazeta da Tarde, 18 jun. 1891.

${ }^{43}$ Até aqui, tudo em Diário de Pernambuco, 4 mar. 1891.

${ }^{44}$ Diário de Pernambuco, 6 e 7 maio 1891; Gazeta da Tarde, 6 maio 1891

${ }^{45}$ Gazeta da Tarde, 24 abr. 1891.

46 Jornal do Recife, 2 e 10 maio 1891; Diário de Pernambuco, 9 maio 1891; Gazeta da Tarde, 9 maio 1891.

47 Jornal do Recife, 9 maio 1891. 
e reivindicaram direitos até então incomuns.$^{48}$ Outro exemplo de confraternização vertical veio da Alfândega, onde os operários do estabelecimento também homenagearam sua chefia pelo mesmo motivo que cigarreiros e alfaiates. ${ }^{49}$ Ainda sobre a conciliação, o Congresso Artístico Operário Pernambucano nutria o profundo desejo de evitar greves, dialogar com as autoridades públicas e encontrar meios pacíficos e lícitos de pleitear o desenvolvimento moral e material da classe trabalhadora. ${ }^{50}$

No tocante ao "desenvolvimento moral" da classe trabalhadora em finais do século retrasado, existiu uma importante demanda internacional vinda de baixo: a educação. ${ }^{51}$ A Liga Operária de Pernambuco proibia que seus associados contratassem aprendizes que não soubessem ler e escrever ou estivessem longe das aulas noturnas. A entidade determinava que os menores de 10 anos sem instrução básica fossem matriculados no Liceu de Artes e Ofícios do Recife ou em outras escolas. ${ }^{52} \mathrm{O}$ referido estabelecimento era administrado pela Sociedade dos Artistas Mecânicos e Liberais e oferecia os cursos primário e secundário, como demonstrei em outros textos (Mac Cord, 2012). Havia outras associações que ofereciam aulas noturnas. A Sociedade União Beneficente dos Maquinistas contava com uma diretoria de aulas e biblioteca. ${ }^{53}$ A Sociedade União Progressiva Central das Artes, por meio de aulas noturnas, oferecia os mesmos níveis de escolarização encontrados no Liceu de Artes e Ofícios do Recife. ${ }^{54}$ As conferências públicas organizadas pelos grupos de trabalhadores especializados pernambucanos também foi um importante recurso para a instrução daqueles que viviam do suor do próprio rosto. O Congresso Artístico Operário Pernambucano e a Sociedade dos Artistas Mecânicos e Liberais foram pródigos em oferecê-las. ${ }^{55}$

\section{Lutas por direitos e a construção de um projeto de lei pela jornada de oito horas de trabalho}

A peculiaridade das lutas dos trabalhadores especializados pernambucanos em relação às demandas europeias foi o franco diálogo com as questões do pósabolição. Para alguns grupos que povoam este texto, era impossível dissociar suas lutas contra a precarização do trabalho (e da liberdade) dos significados

\footnotetext{
48 Aqui faço uma referência direta a uma ideia de Flávio Gomes e Antonio Negro (2006, p. 218), quando dizem que os trabalhadores associados tanto buscavam "proteger seus costumes em comum [quanto] criar direitos incomuns".

49 Diário de Pernambuco, 18 jun. 1891.

50 Apeje. Miscelânea 1891-1892, fl. 330, Seção de Manuscritos, Recife.

${ }^{51}$ As associações de trabalhadores sempre estiveram atentas à relação entre escolarização e elevação moral do proletariado (Andreucci, 1989, p. 44-49). A escolarização do proletariado também tinha por objetivo a formação de quadros (1989, p. 158).

52 Gazeta dos Operários, 15 jul. 1890.

${ }^{53}$ Diário de Pernambuco, 31 mar. 1891.

54 Jornal do Recife, 22 maio e 3 jun. 1891; Diário de Pernambuco, 3 e 5 de jun. 1891.

55 Diário de Pernambuco, 14 e 26 out. e 9 e 23 nov. 1890; Diário de Pernambuco, 8 fev. e 8 ago. 1891. As conferências públicas eram espaços de sociabilização das ciências e de formação da opinião pública (Carula, 2009).
} 
da república e do fim da escravidão. ${ }^{56}$ Uns alimentavam os outros. Em maio de 1890, isso fica evidente quando o Club Artístico Nacional e a Liga Operária de Pernambuco comemoram o dia 13 de Maio. ${ }^{57}$ Em outubro, quando certos artífices construíam a União Artístico-operária Olindense e preparavam seus estatutos, deliberaram que fariam uma confraternização pública sob a regência da Banda Musical 13 de Maio. ${ }^{58}$ Meses depois, oficializada, a entidade com trabalhadores especializados comemorou a festa da Abolição de 1891, que foi organizada pela Sociedade Artística 13 de Maio. Na oportunidade, aquele referido grupo musical também tocou. No repertório, entre outras peças, estava listada a simbólica Marselhesa. Com pompa e circunstância, foi lançada no evento a tipografia $O$ Artista Brasileiro, sob a direção de Evaristo Wanderley. ${ }^{59}$ Artista tipógrafo, esse indivíduo trabalhou no Jornal do Commercio, foi diretor provisório da citada associação olindense e lutou por melhorias para sua categoria profissional. ${ }^{60}$

Por tudo o que discutimos neste texto no tocante às lutas daqueles que viviam do suor do próprio rosto, parece evidente que a estratégia dos grupos de trabalhadores qualificados pernambucanos era vincular suas existências à mais plena liberdade - o que permitiria o gozo de uma cidadania mais qualificada. Isso fica ainda mais evidente em duas conferências públicas organizadas pelo Congresso Artístico e Operário de Pernambuco. Em outubro de 1890, a primeira delas ocorreu em um dos salões do Liceu de Artes e Ofícios do Recife e foi ministrada por Rodolpho Lima. O desenhista e gravador afirmou que os inimigos da classe trabalhadora procuravam "reduzir os artistas e operários a uma escravidão infinita" ${ }^{61}$ A outra palestra foi realizada na cidade de Nazareth no mês de janeiro de 1891. Nesse encontro, João Dez (1893, p. 3) afirmou aos ouvintes que "é verdade que não temos o escravo da Antiguidade, mas temos o proletariado atual, que é uma vítima escravizada e sacrificada pelos egoístas das sociedades modernas". Ainda posso oferecer ao leitor mais um exem-

\footnotetext{
${ }^{56}$ A Abolição e a Proclamação da República radicalizaram o processo que transformou o ex-escravo em trabalhador negro e cidadão da cor preta que talvez pudesse se transformar em "homem civilizado". A partir dos anos 1890, por causa do racismo, as elites brancas, letradas e proprietárias criaram uma isonomia entre os negros, nivelando-os por baixo. Isso gerou grande tensão entre as pessoas de pele escura que haviam conquistado direitos no transcorrer do século. Para saber mais, consultar Gomes (1991, p. 81), Machado (2010, p. 95) e Albuquerque (2009, p. 165). Para saber mais sobre os significados da precarização da liberdade, consultar Chalhoub (2010, p. 33-62) e Lima (2005, p. 289-326). Sidney Chalhoub aprofunda seus argumentos sobre a precarização da liberdade na obra A força da escravidão: ilegalidade e costume no Brasil oitocentista. São Paulo: Companhia das Letras, 2012.

${ }^{57}$ Diário de Pernambuco, 13 e 15 jun. 1891.

${ }_{58}^{5}$ Diário de Pernambuco, 25 out. 1890.

${ }^{59}$ Diário de Pernambuco, 12 maio 1891; Gazeta da Tarde, 15 maio 1891.

60 Diário de Pernambuco, 18 out. e 25 dez. 1890; O Artista, 3 fev. 1891. A participação de categorias e associações profissionais nas festas do dia 13 de Maio, logo após a assinatura da Lei Aurea, não foi uma particularidade pernambucana. No Rio de Janeiro, tipógrafos, funcionários públicos e caixeiros participaram das comemorações, assim como entidades artístico-operárias. Entre elas, a associação Trabalho, União e Moralidade (Moraes, 2012, p. 201-223). As festas da Abolição foram muito importantes para o exercício das manifestações públicas. Para muitos ex-escravos, elas significaram a primeira oportunidade para exprimirem seus desejos como cidadãos livres (Fraga Filho, 2006, p. 126).

${ }^{61}$ Diário de Pernambuco, 28 out. 1890. Encontro a informação de que Rodolpho Lima era desenhista e gravador no jornal O Artista, 3 fev. 1891.
} 
plo da tentativa dos de baixo da pirâmide social para escapar da precarização da liberdade e do trabalho. No dia 6 de março de 1891, o editorial do jornal $O$ Artista afirmou que era passado o tempo da escravidão e que era chegada a hora de a classe artística se elevar. ${ }^{62}$

\section{Se tivemos o acirramento da luta de classes, vários acordos entre patrões e empregados foram bem-sucedidos e terminaram em festa entre os antigos contentores}

Nessa conjuntura, os grupos de trabalhadores especializados pernambucanos construíram uma importante estratégia para qualificar sua cidadania e combater a temida precarização de sua liberdade e mão de obra: pressionar o governo estadual para que aprovasse a lei das oito horas de trabalho diário demanda criada pelo movimento operário do hemisfério norte. Do ponto de vista historiográfico, isso vai ao encontro de questões enfrentadas pelos estudos do pós-Abolição: encarar o trabalho e a cidadania como questões gêmeas e detectar formas de organizar o trabalho livre em ritmos alternativos (Cooper, Holt e Scoot, 2005, p. 53, 63 e 70; Rios e Mattos, 2004, p. 174). Em abril de 1891, no bojo das greves e das lutas salariais oportunamente analisadas, 138 profissionais da Junção dos Pedreiros e Carpinas, entidade filiada ao Congresso Artístico Operário de Pernambuco, escolheram uma comissão para solicitar aos deputados estaduais constituintes, "representantes das artes", a redução da jornada de trabalho.$^{63} \mathrm{Na}$ festa do dia $1^{\circ}$ de Maio, o Congresso Artístico Operário de Pernambuco reforçou a reivindicação da jornada de oito horas de trabalho diárias, mas trouxe uma novidade ao grande público. Uma das mais relevantes especificidades diante das reivindicações de europeus e de estadudinenses foi a substituição das oito horas de lazer por oito horas de estudo. Rodolpho Lima foi o principal orador do evento. ${ }^{64}$

Vimos que a educação formal foi uma das principais demandas da classe trabalhadora organizada, quer em Pernambuco, quer na Europa, quer nos Estados Unidos. Como demonstrei em outro momento deste texto, o domínio da leitura, da escrita e das operações matemáticas foi fundamental para que os artífices pernambucanos combatessem os estigmas da escravidão e do defeito mecânico. A habilidade da escrita e da leitura se tornou algo ainda mais importante com a Lei Saraiva, de 1881, que eliminou a maioria dos analfabetos da vida político-eleitoral. Por causa disso, uma massa de trabalhadores descendentes de africanos foi excluída das eleições a partir daquele momento. A

62 O Artista, 6 mar. 1891. Na Europa, também encontramos apelos às imagens da escravidão quando da luta pela diminuição da jornada de trabalho (Perrot, 2010, p. 149).

${ }^{63}$ Gazeta da Tarde, 24 abr. 1891; Diário de Pernambuco, 25 abr. 1891. O Congresso Constituinte Estadual de Pernambuco foi instalado em 14 de abril de 1891 (Zacarias, 2009, p. 72).

${ }^{64}$ Diário de Pernambuco, 5 maio 1891; Jornal do Recife, 5 maio 1891. 
Constituição de 1891 ratificou a exigência da alfabetização como critério da cidadania política. ${ }^{65}$ Em pesquisa recente, demonstrei que uma elite artesanal recifense, com a pele escura, continuou votando no transcorrer dos anos 1880, apesar daquela excludente norma imperial. Isso permitiu que o grupo desfrutasse de uma sólida economia do favor com deputados gerais e provinciais (Mac Cord, 2014, p. 153-191). Certamente, por intermédio do Congresso Artístico e Operário de Pernambuco, foram os trabalhadores especializados com tal perfil que fizeram e encaminharam a solicitação aos tais deputados estaduais "representantes das artes".

Na medida em que conquistassem a jornada de trabalho de oito horas diárias, os trabalhadores especializados pernambucanos se distinguiriam ainda mais do restante da população desfavorecida do estado, pois desfrutariam de um regime de labuta menos explorador. Eles queriam ampliar a distância social que os separava de homens como Joaquim Cavalcante do Rego Barros, preso pobre da Casa de Detenção do Recife. Em 1891, ele solicitou trabalhar nas oficinas do estabelecimento prisional entre 6 horas da manhã e 5 horas da tarde. Nesse horário, receberia a visita de seus filhos para auxiliá-lo. ${ }^{66}$ As longas 11 horas de trabalho precário seriam utilizadas para satisfazer às suas necessidades e às de sua família, pois certamente não contava com os pecúlios oferecidos pelas sociedades mutualistas. Em decorrência daquela desejada conquista trabalhista, menos horas de labuta permitiria mais tempo livre para os estudos, o que viabilizaria, por exemplo, o aumento da quantidade de artesãos e operários nas listas eleitorais - potencializando o poder político da classe trabalhadora. Nesse sentido, ainda em 1891, a Sociedade Recreio Juvenil Nazareno, atenta às conjunturas, comemorou o fato de suas aulas noturnas terem preparado eleitores para o pleito daquele mesmo ano. ${ }^{67}$

Imersos nessas questões, os grupos de trabalhadores especializados pernambucanos voltaram a pressionar o congresso constituinte estadual em finais de maio e início de junho. Entre eles, o Congresso Artístico Operário de Pernambuco voltou a exigir a criação de uma lei que regulasse a jornada de trabalho e permitisse tempo livre para a educação. ${ }^{68}$ Pouco tempo depois, em setembro de 1891, as petições surtiram efeito - também devemos creditar o sucesso da solicitação às greves, às festas de $1^{\circ}$ e 13 de Maio e à organização de setores da classe trabalhadora pernambucana que estavam atentos às demandas nacionais e internacionais. No dia 2 de setembro, o Diário de Pernambuco reproduziu as atas da Câmara dos Deputados, que relatava a reunião parlamentar da véspera. No documento, observamos que foi lido e julgado "um projeto que tomou o número 10, assinado pelos Srs. Telles Junior e outros, marcando 8 horas diárias para o trabalho dos operários".

65 Sobre a reforma eleitoral de 1881 e a questão eleitoral na Constituição de 1891, consultar Carvalho (2010), Costa (1977), Dias (2005, p. 57-72), Graham (1997) e Souza (2014)

${ }^{66}$ Apeje. Casa de Detenção do Recife, CDR 2.12/57, folha sem numeração, Seção de Manuscritos, Recife.

${ }^{67}$ Apeje. Intendência Municipal, IM 06, fl. 358, Seção de Manuscritos, Recife.

${ }^{68}$ Diário de Pernambuco, 30 maio 1891; Jornal do Recife, 30 maio 1891; Gazeta da Tarde, 10 jun. 1891. 
Ainda segundo a fonte, "esse projeto foi, antes de enviado à mesa, justificado pelo Sr. Telles Junior, o primeiro de seus signatários". Ainda em mesma edição do jornal, mas em uma nota intitulada "Horas de trabalho", ficamos sabendo que o "deputado artista Telles Junior" era um "representante da Liga Operária no Congresso". ${ }^{9}$

No tocante ao "desenvolvimento moral" da classe
trabalhadora em finais do século retrasado,
existiu uma importante demanda internacional vinda
de baixo: a educação

No período em quadro, o recifense Jerônimo José Telles Junior era um reconhecido pintor de quadros. É bastante provável que tenha conquistado a simpatia (ou a tolerância) de setores da classe trabalhadora porque era ex-maquinista, ex-limador, aliado de José Mariano (político liberal, popular e com ideais republicanos) e dirigente da Sociedade dos Artistas Mecânicos e Liberais. ${ }^{70} \mathrm{O}$ Partido Operário de Pernambuco, braço eleitoral da Liga Operária de Pernambuco, apoiou o nome de Telles Junior quando lançou um ousado programa político-eleitoral que objetivava disputar o maior número possível de cadeiras oferecidas pela Constituinte estadual. Entre outros tópicos, o documento defendia a igualdade entre ricos e pobres, a luta por leis sociais, a necessidade da jornada de oito horas diárias, o direito à aposentadoria, o acesso da classe trabalhadora à escola e a mudança do regime de trabalho das mulheres e das crianças. ${ }^{71}$ Nomes mais representativos, como o de Rodolpho Lima, estavam na lista do Partido Operário de Pernambuco para o pleito de 1891, mas não foram eleitos. Pelo menos desde a década de 1860, os artistas mecânicos pernambucanos tentavam conquistar o lugar de deputado, mas nunca conseguiram ocupá-lo. Por mais que alguns deles quisessem sair candidatos, ora eram preteridos pelos partidos oficiais, ora cediam às conveniências de seus patronos (Mac Cord, 2012 e 2014, p. 153-191).

No transcorrer da primeira quinzena de setembro, o Projeto de Lei no 10 passou por três discussões parlamentares e foi emendado pelo deputado estadual

\footnotetext{
69 Até aqui, tudo em Diário de Pernambuco, 2 set. 1891.

70 Recifense nascido em 1851, até seus 14 anos estudou em escolas particulares e em casa, dividindo sua vida entre Pernambuco e Rio Grande do Sul - terra de seus pais. Aos 16, foi caixeiro nessa última localidade, mas dirigia sua atenção para a mecânica. Como seu pai era comandante de navio, aprendeu rudimentos daquela arte com um maquinista inglês. Foi aprendiz de limador. Embarcou para o Rio de Janeiro e frequentou o Arsenal de Marinha, onde aprendeu desenho e se aperfeiçoou na oficina de limador. No Liceu de Artes e Ofícios, desenvolveu seus talentos na pintura. Retornou ao Rio Grande do Sul para trabalhar no comércio. Voltou a Recife para labutar no mesmo ramo e se casou com sua prima. Em 1880, por causa da pintura (tinha um ateliê), passou a fazer parte dos quadros da Sociedade dos Artistas Mecânicos e Liberais. José Mariano, líder dos "cachorros", representados pelas camadas médias urbanas e liberais, indicou o ex-mecânico e reconhecido pintor de quadros para representar a classe artístico-operária no legislativo estadual (Telles Junior, 1954).

${ }^{71}$ Gazeta da Tarde, 3 mar. 1891.
} 
Faustino Porto. ${ }^{72} \mathrm{O}$ artigo $1^{\circ}$ definia que "o número de horas de trabalho para o operário fica reduzido a oito por dia", mas recebeu a seguinte complementação: "salvo acordo entre as partes em sentido contrário" (Bandeira, Melo e Andrade, 1967, p. 12-13). Após a segunda discussão sobre a emenda, o reformado projeto de lei foi aprovado e seguiu para a comissão de redação. ${ }^{73}$ Fica evidente o viés liberal do processo que mudou o texto proposto pelo deputado estadual Telles Junior. Se o documento original era fruto das pressões vindas de setores da classe trabalhadora pernambucana, que ansiava por legislação social, o documento modificado foi ao encontro dos interesses políticos e econômicos da república do Brasil, que, no caso do mundo do trabalho, queria fomentar processos de negociação direta entre patronato e proletariado. ${ }^{74}$ Texto pronto no dia 12, a Secretaria da Câmara dos Deputados se preparou para enviá-lo ao Senado de Pernambuco, uma vez que o Legislativo era bicameral. ${ }^{75} \mathrm{O}$ documento foi recebido por esta última casa no dia 14 . No início de outubro, foi discutido e reprovado. A aristocracia senatorial não tolerou nem mesmo a possibilidade de qualquer sopro de direitos trabalhistas. ${ }^{76}$

\section{Considerações finais}

Em Pernambuco dos primeiros anos do regime republicano, o Projeto de Lei no 10 não saiu do papel. Apesar disso, esse texto vai ao encontro de uma importante análise de Silvia Lara e Joseli Mendonça (2006, p. 13), quando se debruçaram sobre o processo de elaboração das leis. Baseadas em novas abordagens historiográficas, elas perceberam que a constituição de um "espaço público para a regulamentação das relações de trabalho [...] nem sempre caminhou contra e à revelia dos desejos dos trabalhadores". Nesse sentido, por mais que os trabalhadores especializados pernambucanos ficassem melindrados com a derrota legislativa de sua demanda, ganharam a certeza de que sua voz tinha ressonância. Sabedores disso, por meio de suas entidades começaram a pressionar os patrões, negociando diretamente a jornada de trabalho de oito horas. Em novembro de 1891, por exemplo, um grupo de carpinteiros e de calafates pediu ajuda à Liga Operária de Pernambuco. Costumeiramente, eles entravam na oficina às $6 \mathrm{~h} 30$. Saíam entre $16 \mathrm{~h} 30 \mathrm{e} 17 \mathrm{~h}$. A negociação permitiu que aqueles artesãos labutassem das $7 \mathrm{~h}$ às $16 \mathrm{~h}$, mas com intervalo de uma hora de almoço. ${ }^{77}$ A mesma entidade conseguiu outra vitória semelhante no mesmo mês. ${ }^{78}$

\footnotetext{
72 Diário de Pernambuco, 3-6 set. 1891

73 Diário de Pernambuco, 10 set. 1891.

74 Sobre as tensões da livre negociação entre patrões e empregados e as lutas da classe operária por legislação social, ver Neder (2012, p. 59-60)

${ }^{75}$ Assembleia Legislativa de Pernambuco (Alepe). Ofícios Recebidos, OR 71, folha sem numeração, Seção de Manuscritos, Recife.

76 Alepe. Diário de Pernambuco, 2, 7 e 9 out. 1891. Atas do Senado, 1891-1892, Sessão de 14 de setembro, Sessões de 1o, 5, 6, 8 e 9 out., folhas sem numeração, Seção de Manuscritos, Recife.

77 Diário de Pernambuco, 22 nov. 1891.

78 Diário de Pernambuco, 29 nov. 1891
} 
$\mathrm{O}$ artigo chega às suas últimas linhas com a certeza de que demonstrou as expectativas de operários e artífices pernambucanos quanto a seu futuro, mesmo que precisassem encarar os fluxos e refluxos dessa sensação. Parece evidente que eles não receberam o regime republicano de forma bestializada, como defendeu a história política mais tradicional. Apostando nas possibilidades de transformação, reinventaram suas "velhas" lutas por direitos, que, desde os tempos de d. Pedro II, foram organizadas em irmandades e sociedades mutualistas. Absolutamente conectadas com o que estava acontecendo no mundo do trabalho brasileiro e estrangeiro, as "classes laboriosas" pernambucanas criaram novas entidades que pleitearam educação formal, melhores condições de trabalho e aprofundamento da cidadania - por meio das festas de $1^{\circ}$ e 13 de Maio e de outras variadas estratégias que envolveram as lutas por oito horas diárias de trabalho. A nova historiografia social do trabalho demonstrou que o ânimo dos trabalhadores brasileiros, logo após os primeiros anos do regime republicano, foi paulatinamente solapado, pois as promessas republicanas não foram cumpridas (Batalha, 2006, p. 107). Contudo, esse é outro momento de minha investigação, que não cabe esmiuçar em um artigo que apenas se debruçou sobre as primeiras histórias de luta e de esperança na Primeira República.

Não há dúvidas também de que analisei um grupo mais restrito de trabalhadores, que contava com artífices especializados e operários relativamente qualificados. Caso o Projeto de Lei no 10 tivesse saído do papel como foi concebido, e até mesmo com a emenda que sofreu, certamente criaria um direito que seria usufruído por uma parcela da classe trabalhadora pernambucana. E esse era mesmo o objetivo daqueles que lutaram pela jornada de oito horas de trabalho no início dos anos 1890, especialmente quando descendentes de africanos. Eles queriam se consolidar/estabelecer como uma aristocracia do trabalho "autorreconhecida e reconhecida pelos outros como uma camada superior e até certo ponto separada do restante" (Hobsbawm, 2000, p. 264) para que, em meu ponto de vista, pudessem construir uma liberdade o menos precária possível em contextos de pós-Abolição. Apesar da escala reduzida da pesquisa e da construção de uma identidade de classe verticalizada, não há como negar a importância dos eventos analisados na formação da classe trabalhadora brasileira, ainda tão diversa em sua composição, interesses, solidariedades e estratégias. 


\section{Referências bibliográficas}

ALBUQUERQUE, Wlamyra R. de. O jogo da dissimulação: abolição e cidadania negra no Brasil. São Paulo: Companhia das Letras, 2009.

ANDREUCCI, Franco. A difusão e a vulgarização do marxismo. In: HOBSBAWM, Eric. J. (Org.). História do marxismo: o marxismo na época da Segunda Internacional. 3. ed. Rio de Janeiro: Paz e Terra, 1989. v. 2, 1. parte.

BANDEIRA, Muniz; MELO, Clovis; ANDRADE, A. T. O ano vermelho: a Revolução Russa e seus reflexos no Brasil. Rio de Janeiro: Civilização Brasileira, 1967.

BATALHA, Claudio H. de M. A historiografia da classe operária no Brasil: trajetórias e tendências. In: FREITAS, Marcos C. (Org.). Historiografia brasileira em perspectiva. São Paulo: Contexto, 2003. (Coord.). Dicionário do movimento operário: Rio de Janeiro do século XIX aos anos 1920 — militantes e organizações. São Paulo: Fundação Perseu Abramo/Fapesp, 2009.

. Formação da classe operária e projetos de identidade coletiva. In: FERREIRA, Jorge;

DELGADO, Lucila de A. N. (Org.). O Brasil republicano: o tempo do liberalismo excludente: da Proclamação da República à Revolução de 1930. 4. ed. Rio de Janeiro: Civilização Brasileira, 2010. livro 1.

. Identidade da classe operária no Brasil (1880-1920): atipicidade ou legitimidade?. Revista Brasileira de História, São Paulo, v. 12, n. 23-24, p. 111-124, set. 1991/ago. 1992.

. Limites da liberdade: trabalhadores, relações de trabalho e cidadania durante a Primeira República. In: LIBBY, Douglas C.; FURTADO, Júnia F. (Org.). Trabalho livre, trabalho escravo: Brasil e Europa, séculos XVIII e XIX. São Paulo: Annablume, 2006.

. O movimento operário na Primeira República. Rio de Janeiro: Zahar, 2000.

. et al. (Org.). Culturas de classe: identidade e diversidade na formação do operariado. Campinas: Unicamp, 2004.

CÂMARA, Bruno A. D. Trabalho livre no Brasil imperial: o caso dos caixeiros de comércio na época da Insurreição Praieira. Dissertação (Mestrado), Universidade Federal de Pernambuco, Recife, 2005.

CARULA, Karoline. A tribuna da ciência: as conferências populares da Glória e as discussões do darwinismo na imprensa carioca. São Paulo: Annablume/Fapesp, 2009.

CARVALHO, José M. de. Cidadania no Brasil: o longo caminho. 13. ed. Rio de Janeiro: Civilização Brasileira, 2010.

. Os bestializados: o Rio de Janeiro e a república que não foi. 3. ed., 22. reimp. São Paulo: Companhia das Letras, 2013.

CARVALHO, Marcus J. M. de. Os nomes da revolução: lideranças populares na Insurreição Praieira, Recife, 1848-1849. Revista Brasileira de História, São Paulo, v. 23, n. 45, 2003.

CASTELLUCCI, Aldrin. Trabalhadores, máquina política e eleições na Primeira República. Tese (Doutorado), Universidade Federal da Bahia, Salvador, 2008.

CHALHOUB, Sidney. Precariedade estrutural: o problema da liberdade no Brasil escravista (século XIX). História Social, Campinas, n. 19, p. 33-62, 2010.

; SILVA, Fernando T. da. Sujeitos no imaginário acadêmico: escravos e trabalhadores na historiografia brasileira desde os anos 1980. Cadernos AEL, Campinas, v. 14, p. 11-50, 2009. COOPER, Frederick; HOLT, Thomas C.; SCOOT, Rebecca J. (Org.). Além da escravidão: investigações sobre raça, trabalho e cidadania em sociedades pós-emancipação. Rio de Janeiro: Civilização Brasileira, 2005.

COSTA, Emília V. da. Da monarquia à república: momentos decisivos. São Paulo: Grijalbo, 1977. CRUZ, Maria C. Velasco e. Tradições negras na formação de um sindicato: Sociedade de Resistência dos Trabalhadores em Trapiche e Café, Rio de Janeiro, 1905-1930. Afro-Ásia, Salvador, n. 24, p. 243-290, 2000.

DEZ, João. Conferência artística realizada na cidade de Nazareth em 18 de janeiro de 1891 em nome do Congresso Artístico Operário de Pernambuco. Recife: Typographia do Jornal do Recife, 1893. DIAS, Maria Odila L. da S. Sociabilidades sem história: votantes pobres no império, 1824-1881. In: FREITAS, Marcos C. (Org.). Historiografia brasileira em perspectiva. São Paulo: Contexto, 2005. FETSCHER, Iring. Bernstein e o desafio à ortodoxia. In: HOBSBAWM, Eric. J. (Org.). História do marxismo: o marxismo na época da Segunda Internacional. 3. ed. Rio de Janeiro: Paz e Terra, 1989. v. 2, 1. parte. 
FONTES, Paulo. Trabalhadores e cidadãos: Nitro-Química: a fábrica e as lutas operárias nos anos 50. São Paulo: Annablume, 2007.

FORTES, Alexandre. Nós do Quarto Distrito: a classe trabalhadora porto-alegrense e a Era Vargas. Caxias do Sul: Educs; Rio de Janeiro: Garamond, 2004.

et al. (Org.). Na luta por direitos: estudos recentes em história social do trabalho. Campinas: Unicamp, 1999.

FRAGA FILHO, Walter. Encruzilhadas da liberdade: história de escravos e libertos na Bahia (1870-1910). Campinas: Unicamp, 2006.

GOMES, Angela de C. A invenção do trabalhismo. 3. ed. Rio de Janeiro: FGV, 2005.

. Questão social e historiografia no Brasil do pós-1980: notas para um debate. Estudos Históricos, Rio de Janeiro, n. 34, p. 157-186, 2004.

; FERREIRA, Marieta de M. Industrialização e classe trabalhadora no Rio de Janeiro: novas perspectivas de análise. Boletim Informativo e Bibliográfico de Ciências Sociais (BIB), Rio de Janeiro, n. 24, p. 11-40, 1987.

GOMES, Flávio dos S. No meio das águas turvas (racismo e cidadania no alvorecer da república: a Guarda Negra na Corte - 1888-1889). Estudos Afro-Asiáticos, Rio de Janeiro, n. 21, p. 81, 1991. ; MACHADO, Maria Helena P. T. Da Abolição ao pós-emancipação: ensaiando alguns caminhos para outros percursos. In: MACHADO, Maria Helena P. T.; CASTILHO, Celso T. (Org.). Tornando-se livres: agentes históricos e lutas sociais no processo de Abolição. São Paulo: Universidade de São Paulo, 2015.

GRAHAM, Richard. Clientelismo e política no Brasil do século XIX. Rio de Janeiro: UFRJ, 1997.

HALL, Michael M.; PINHEIRO, Paulo S. Alargando a história da classe operária: organização, lutas e controle. Remate de Males, Campinas, n. 5, p. 95-119, 1985.

HAUPT, G. Marx e o marxismo. In: HOBSBAWM, Eric. J. (Org.). História do marxismo: o marxismo no tempo de Marx. 3. ed. Rio de Janeiro: Paz e Terra, 1983. v. 1.

HOBSBAWM, Eric. J. A cultura europeia e o marxismo entre o século XIX e o século XX. In: (Org.). História do marxismo: o marxismo na época da Segunda Internacional. 3. ed. Rio de Janeiro: Paz e Terra, 1989. v. 2, 1. parte.

. Mundos do trabalho: novos estudos sobre história operária. 3. ed. rev. São Paulo: Paz e Terra, 2000.

JESUS, Ronaldo P. de. História e historiografia do fenômeno associativo no Brasil monárquico (1860-1887). In: CARVALHO, Carla M. de; OLIVEIRA, Mônica Ribeiro de (Org.). Nomes e números: alternativas metodológicas para a história econômica e social. Juiz de Fora: UFJF, 2006.

JOFILLY, Mariana. O socialismo na França e no Brasil durante a II Internacional Socialista (18891918). São Paulo: Alameda, 2012.

LACERDA, David P. Solidariedades entre ofícios: a experiência mutualista no Rio de Janeiro imperial (1860-1882). Dissertação (Mestrado), Universidade Estadual de Campinas, Campinas, 2011. LARA, Silvia H. Blowin' in the wind: Thompson e a experiência negra no Brasil. Projeto História, São Paulo, n. 12, p. 43-56, 1995.

. Escravidão, cidadania e história do trabalho no Brasil. Projeto História, São Paulo, n. 16, p. 25-38, 1998.

; MENDONÇA, Joseli M. N. Apresentação. In: Direitos e justiça no Brasil: ensaios de história social. Campinas: Unicamp, 2006.

LIMA, Henrique E. Sob o domínio da precariedade: escravidão e os significados da liberdade de trabalho no século XIX. Topoi, Rio de Janeiro, v. 6, n. 11, p. 289-326, 2005.

LORNER, Beatriz. Construção de classe: operários de Pelotas e Rio Grande (1888-1930). Pelotas: Universitária/Unitrabalho, 2001.

MAC CORD, Marcelo. Artífices da cidadania: mutualismo, educação e trabalho no Recife oitocentista. Campinas: Unicamp, 2012.

. A União Artística: construção e legitimidade de uma entidade de classe, Recife, década de 1870. Perseu, São Paulo, ano 3, n. 4, p. 41-63, 2009.

. Imperial Sociedade dos Artistas Mecânicos e Liberais: mutualismo, cidadania e a reforma eleitoral de 1881 no Recife. In:___ _ _ BATALHA, Claudio H. de M. (Org.). Organizar e proteger: trabalhadores, associações e mutualismo no Brasil (séculos XIX e XX). Campinas: Unicamp, 2014. MACHADO, Maria Helena P. T. O plano e o pânico: os movimentos sociais na década de abolição. 2. ed. rev. São Paulo: Edusp, 2010. 
MATTOS, Hebe M. Das cores do silêncio: os significados da liberdade no Sudeste escravista Brasil, século XIX. 2. ed. Rio de Janeiro: Nova Fronteira, 1998.

MATTOS, Marcelo B. Escravizados e livres: experiências comuns na formação da classe trabalhadora carioca. Rio de Janeiro: Bom Texto, 2008.

MELLO, Maria T. de C. A república consentida: cultura democrática e científica do final do império. Rio de Janeiro: FGV/UFRRJ, 2007.

MORAES, Renata F. As festas da Abolição: o 13 de Maio e seus significados no Rio de Janeiro (1888-1908). Tese (Doutorado), Pontifícia Universidade Católica, Rio de Janeiro, 2012.

NEDER, Gizlene. Discurso jurídico e ordem burguesa no Brasil: criminalidade, justiça e constituição do mercado de trabalho (1890-1927). 2. ed. rev. e amp. Niterói: UFF, 2012.

NEGRO, Antonio L. Imperfeita ou refeita? O debate sobre o fazer-se da classe trabalhadora inglesa. Revista Brasileira de História, São Paulo, v. 16, n. 31-32, p. 40-61, 1996.

; GOMES, Flávio dos S. Além das senzalas e das fábricas: uma história social do trabalho. Tempo Social: Revista de Sociologia da USP, São Paulo, v. 18, n. 1, p. 218, 2006.

NEGT, Oskar. O marxismo e a teoria da revolução no último Engels. In: HOBSBAWM, Eric. J. (Org.). História do marxismo: o marxismo na época da Segunda Internacional. 3. ed. Rio de Janeiro: Paz e Terra, 1989. v. 2, 1. parte.

PANSARDI, Marcus V. Republicanos e operários: os primeiros anos do movimento socialista no Brasil (1889-1903). Dissertação (Mestrado), Universidade Estadual de Campinas, Campinas, 1993. PERROT, Michele. Os excluídos da história: operários, mulheres e prisioneiros. 6. reimp. São Paulo: Paz e Terra, 2010.

PETERSEN, Silvia R. F. Cruzando fronteiras: as pesquisas regionais e a história operária brasileira. Anos 90, Porto Alegre, n. 3, p. 135, 1995.

PINHEIRO, Paulo S. Trabalho industrial no Brasil: uma revisão. Estudos Cebrap, São Paulo, n. 14, p. 120-131, 1975.

; HALL, Michael M. A classe operária no Brasil, 1889-1930: documentos. São Paulo: Alfa Ômega, 1979. v. 1.

. A classe operária no Brasil, 1889-1930: condições de vida e de trabalho, relações com os empregados e o Estado. São Paulo: Brasiliense, 1981. v. 2.

RIOS, Ana Maria L.; MATTOS, Hebe M. Memórias do cativeiro: família, trabalho e cidadania no pós-Abolição. Rio de Janeiro: Civilização Brasileira, 2005.

; ___ O pós-Abolição como problema histórico: balanços e perspectivas. Topoi, Rio de Janeiro, v. 5, n. 8, p. 174, 2004.

;____. Para além das senzalas: campesinato, política e trabalho rural no Rio de Janeiro pós-Abolição. In: CUNHA, Olívia M. Gomes da; GOMES, Flávio dos S. (Org.). Quase-cidadão: histórias e antropologias da pós-emancipação no Brasil. Rio de Janeiro: FGV, 2007.

RODRIGUES, José A. Sindicato e desenvolvimento no Brasil. São Paulo: Difusão Europeia do Livro, 1968.

SOUZA, Felipe Azevedo e. O eleitorado imperial em reforma. Recife: Fundação Joaquim Nabuco/ Massangana, 2014.

TELLES JUNIOR, Jerônimo J. Memórias. Recife: Arquivo Público Estadual, 1954. Datilografado. THOMPSON, E. P. A formação da classe operária inglesa: a árvore da liberdade. 3. ed. Rio de Janeiro: Paz e Terra, 1997. v. 1.

. A miséria da teoria ou um planetário de erros: uma crítica ao pensamento de Althusser. Rio de Janeiro: Zahar, 1981.

WALDENBERG, Marek. A estratégia política da social-democracia alemã. In: HOBSBAWM, Eric. J. (Org.). História do marxismo: o marxismo na época da Segunda Internacional. 3. ed. Rio de Janeiro: Paz e Terra, 1989. v. 2, 1. parte.

ZACARIAS, Audenice A. dos S. Legalidade e autoridade: a implementação da república no estado de Pernambuco (1889-1893). Dissertação (Mestrado), Universidade Federal da Pernambuco, Recife, 2009. 